\title{
Similarities between oocytes and macrophages. An overview
}

\author{
Nirmal Kumar Mishra
}

PG Department of Zoology, Patna University, Patna 800005, India

\begin{abstract}
Oocytes behave as macrophages as they internalize solid and liquid substances required for their growth and competence. This activity is more pronounced in lower invertebrates. The slowing of endocytic activity may be caused by constraints imposed by surrounding nurse cells and by the amount of accumulated yolk precursors. The genes concerned with endocytic activity in oocytes are controlled by a negative feedback signal provided by accumulated yolk and/or by signal transduction. (Folia Histochemica et Cytobiologica 2011; Vol. 49, No. 1, pp. 8-9)
\end{abstract}

Key words: oocytes, macrophage, phagocytosis, ooogenesis

\section{Introduction}

Germ cells originate from the mesoderm and congregate in the gonad. In the female, these cells divide mitotically to create a population of primary oocytes, which are groomed to become the 'queen of cells' with a capacity to perpetuate life. This encompasses a series of biochemical events such as amplification of the ribosomal RNA gene, biogenesis of organelles, vitellogenesis, germinal vesicle breakdown, and the formation of additional membranes. This commentary concentrates on a basic attribute of the growing oocyte, i.e. its propensity to endocytose the materials that make it competent for its subsequent tasks.

In sponges, oocytes develop from choanocytes, and migrate to an area from where they can be released outside. After their migration, the oocytes begin to phagocytose choanocytes and mesenchyme cells [1].

In marine sponges, oocytes begin to engulf nurse cells as soon as they reach a certain size [2].

In hydra, several of the nurse cells undergo fragmentation by partial apoptosis, and the fragmented pieces are phagocytosed by the growing oocytes [3-5].

In jellyfish, oocytes develop from gastrodermal cells. They may remain associated with or without tro-

Correspondence address: NK Mishra,

Patna Univ. 21 Prakash Kunj Apt. Kavi Raman Path,

East Boring Road, Patna 800001, India;

e-mail: neerm1940@yahoo.co.in phocytes. When associated with trophocytes, the latter provide nutrition to the developing oocytes.

But in all types of oocytes, intraooplasmic channels act as conduits for the uptake of yolk precursors, and vitellogenesis occurs in them, partly by autosynthetic, and partly by heterosynthetic, means [5]. In the marine triclad, Cercyra hastate, previtellogenic oocytes resort to an autosynthetic mode of yolk formation, and phagocytosis becomes the means of incorporation of raw materials [6].

One of the earliest accounts of the phagocytic activity of young oocytes was given by Vejdovsky [1884] in Rhynchelmis, as mentioned in a memoir on Tubifex (an oligochaete) written by Dixon [7]. Vejdovsky reported that oocytes become amoeboid and ingest cells around them as they move to the coelomic cavity. Tubifex oocytes develop from the visceral layer of the intestinal epithelium. As young oocytes begin to migrate centrifugally, they shove through the chloragogen cells and engulf a part, or all, of their cellular content. These oocytes show phagocytic invaginations, maintaining their overall shape. Although the chloragogen cells generally store excretory matter collected from the coelomic fluid, some of them act as reservoirs of nutritive substances. The chloragogen cells that were phagocytosed contained ferritin granules in their cytoplasm $[8,9]$. In Nicolea zostericola, a polycheate, developing oocytes engulf agranular amoebocytes that obtain nutrients from the food reserves stored in the parietal epithelium [10].

In other annelids, where the ovary as an organ becomes organized, there is evidence for both auto- 
and heterosynthetic modes of yolk formation incorporating yolk precursors from blood cells. [11, 12].

In leeches, nurse cells, which are also called trophocytes, provide cytoplasmic organelles to the oocytes by way of transport through the oolemma, and some of them are even sacrificed for this purpose [13, 14].

In higher invertebrates, oocytes are hemmed in by a group of follicle/nurse cells. Yolk precursors and yolk proteins come from the fat body in insects or hepatopancreas in crustaceans and scorpions, which are internalized by oocytes through endocytosis. In some bugs, oocytes may project a filopodia-like process that penetrates the cluster of follicle cells so as to obtain food from them [15].

In vertebrates, the basic tenet of internalization and accumulation of yolk proteins in primary oocytes is maintained. The liver remains a major source for the production of blood and yolk proteins. Several authors showed in the early 1970s that the yolk protein precursors (vitellogenin) are produced in the liver, and these are then sequestered in the bloodstream to be internalized through the channels in the oolemma membrane of the growing amphibian oocytes [16].

Jorgensen et al. [17] found a new class of proteins in Xenopus and named it seryp, which is a constituent of yolk protein massed in the yolk platelets. This protein acts as a signature protein of the yolk platelet as it is degraded earlier in the embryonic cells to provide nutrition. The uptake of types and amounts of proteins varies during the course of oocyte development, as they are synthesized by the liver and sequestered in the blood.

Marteil et al. [18] reported the presence of a class of proteins, EP45, in growing oocytes of stage VI, which belongs to a class of seryp. This protein is involved in the meiotic maturation of the oocytes, as evidenced by the germinal vesicle breakdown.

A macrophage-like property is retained by a mature oocyte (ovum) at the time of fertilization, when it incorporates the rostral part of the acrosome of the sperm head within the vesicle, which has been described as a quasi-phagocytic event [19].

Phagocytic activity in oocytes may be asymptotic due to constraints imposed by the accumulation of yolk precursors. Differences in gene expression causing phagocytosis at different stages of oocyte growth may be due to the progressive accumulation of yolk materials in the ooplasm by some negative feedback signal [20].

\section{Acknowledgements}

This review is dedicated to the memory of the late Madhuri Mishra.

The encouragement received from J. Jagdeo and U. Devi is deeply appreciated.

\section{References}

1. Franzen W. Oogenesis and larval development of Scypha ciliata (Porifera: calcarea). Zoomorphol. 1988;107:349-357.

2. Fell PE. The involvement of nurse cells in oogenesis and embryonic development in the marine sponge. Haliclona ecbasis. J Morph. 2005;127:133-149.

3. Technau U, Miller MA, Bridge D, Steele RE. Arrested apoptosis of nurse cells during embryogenesis. Dev Biol. 2003;260:191-206.

4. Alexandrova O, Schade M, Botter A, David CN. Oogenesis in Hydra: nurse cells transfer cytoplasm directly to the growing oocyte. Dev Biol. 2005;281:91-101.

5. Eckelbarger KJ, Larson R. Ultra structure of the ovary and oogenesis in the jellyfish Linuche unguiculata and Stomolaphus meleagris, with a review of ovarian structure in the Scyphozoa. Marine Biol. 1992;114:633-643.

6. Gremigni V, Nigro M. An ultrastructural study of oogenesis in a marine triclad. Tissue Cell. 1983;15:405-415.

7. Dixon GC. Tubifex, L.M.B.C. Memoir. Williams and Norgate, London 1915

8. Mishra NK. On the phagocytic activity of the oocytes of Tubifex sp. Patna Univ J. 1965;20:3-40.

9. Mishap NK. Phagocytosis of chloragogen cells by oocytes of Tubifex sp. Annals Zool. 1968;5:75-83.

10. Eckelbarger KJ. Origin and development of the amoebocytes of Nicolea zostericola (Polychaeta: Terebellidae) with a discussion of their possible role in oogenesis. Marine Biol. 1976;36:169-182.

11. Eckelbarger KJ. Ultrastructural evidence for both autosynthetic and heterosynthetic yolk formation in the oocytes of an annelid (Phragmatopoma lapidosa: Polychaeta). Tissue Cell. 1979;11:425-443.

12. Siekierska E. The structure of the ovary and oogenesis in the earthworm, Dendrobaena veneta (Annelida, Clitellata). Tissue Cell. 2003;35:252-259.

13. Spalek-Wolczynska A, Klag J, Bielecki A, Swiatek P. Oogenesis in four species of Pisicola (Hirudinea, Rhynchobdella). J Morph. 2008;269:18-28.

14. Swiatek P. Structure of the germinal vesicle during oogenesis in leech Glossiphonia heterochita (Annelida, Hirudinea, Rhynchobdellida). J Morph. 2005;263:330-339.

15. Fleig R, Gutzeit HO, Engels W. Structural organization of ovarian follicle cells in the cotton bug (Dysdercus intermedius) and the honey bee (Apis mellifera). Cell Tissue Res. 1991;265:297-305.

16. Wallace RA, Jared DW. Protein incorporation by isolated amphibian oocytes V. Specificity for vitellogenin incorporation. J Cell Biol. 1976;69:345-351.

17. Jorgensen P, Steen JA, Steen H, Kirschner MW. The mechanism and pattern of yolk consumption provide insight into embryonic nutrition in Xenopus. Development. 2009; 136:1539-1548

18. Marteil G, D'Inca R, Pascal A et al. EP45 accumulates in growing Xenopus laevis oocytes and has oocyte-maturation-enhancing activity involved in oocyte quality. J Cell Sci. 2010;15,123:1805-1813.

19. Bronson R. Is the oocyte a non-professional phagocyte? $\mathrm{Hu}$ man Rep. 1998;4:763-775.

20. Brown PT, Herbert P, Woodruff RI. Vitellogenesis in Oncopeltus fasciatus PLC/IP (3), DAG/PK-C pathway triggered by CaM. J Insect Physiol. 2010;56:1300-1305.

Submitted: 11 August, 2010

Accepted after reviews: 13 January, 2011 